Revista de la red interuniversitaria de estudios sobre las literaturas rioplatenses contemporáneas en Francia

$14 \mid 2016$

Levrero

\title{
Introito : Billy Carter y la paciente taciturna
}

Jorge Varlotta

\section{OpenEdition}

Journals

Edición electrónica

URL: http://journals.openedition.org/lirico/2304

DOI: $10.4000 /$ lirico.2304

ISSN: 2262-8339

Editor

Réseau interuniversitaire d'étude des littératures contemporaines du Río de la Plata

Referencia electrónica

Jorge Varlotta, «Introito : Billy Carter y la paciente taciturna », Cuadernos LIRICO [En línea], 14 | 2016

Puesto en línea el 07 junio 2016, consultado el 01 mayo 2019. URL : http://journals.openedition.org/ lirico/2304 ; DOl : 10.4000/lirico.2304

Este documento fue generado automáticamente el 1 mayo 2019.

\section{(c) $(1) \Theta \Theta$}

Cuadernos LIRICO está distribuido bajo una Licencia Creative Commons Atribución-NoComercialSinDerivar 4.0 Internacional. 


\title{
Introito : Billy Carter y la paciente taciturna
}

\author{
Jorge Varlotta
}

1 De regreso en la ciudad después de un largo viaje, Billy Carter se descolgó asido de una soga y dando un alarido a través de la ventana de su oficina de la calle Baker [sic]. Cayó muellemente sobre su sillón favorito, -tapizado en cuero de Rusia- ubicado entre la ventana y el escritorio de caoba. Cerró los ojos y los apretó levemente con el pulgar y el índice de la mano izquierda, mientras la derecha reposaba sobre el brazo correspondiente del sillón. Suspiró.

2 Había sido una siniestra aventura. A duras penas había logrado salvar el pellejo de su ayudante Tinker, y el suyo propio. Sólo mediante una prodigiosa magia verbal había conseguido convertir a Lord Ponsonby de acusador en acusado, logrando que sus propios parientes y amigos lo lincharan antes de que pudiera argumentar una defensa que, probablemente, habría significado el fin de la carrera de Billy Carter. Pero luego, el tenebroso viaje de regreso, a solas con su conciencia : esos días interminables a lomo de yak, y la fatigante monotonía del ferrocarril, repleto de monjas, con todo el tiempo del mundo para pensar. Pobre, inocente, Lord Ponsonby.

3 Y ahora, a enfrentar un presente y un futuro inciertos. Abrió los ojos.

4 Se sorprendió al comprobar que una mujer lo miraba fijamente desde el otro lado del escritorio, sentada rígida en el banquito rojo de los clientes.

5 "Una nueva aventura -pensó Billy, y de sus labios escapó un leve gemido, semejante al susurro de la brisa otoñal entre las hojas plateadas de un álamo joven. No he tenido oportunidad siquiera de darme una ducha y afeitarme, y he aquí una cliente con problemas. Problemas muy graves, según puedo deducir por la crispación de su rostro. Apenas he concluido un trabajo que me ha fatigado, me ha asustado y conflictuado, y del que apenas si he logrado salir entero, para encontrarme ahora frente a esta mujer que no oi entrar, que me mira fijamente, con ese rostro crispado, sin decir palabra, sin parpadear siquiera".

6 Un tercer suspiro, profundo, y acomodó el nudo de su corbata carmesí a finísimas rayas verticales de color blanco; se echó hacia atrás en el mullido sillón: sonrió 
profesionalmente aunque por dentro se sintiera incómodo e irritado : extrajo la cigarrera dorada que portaba un monograma con sus iniciales y de ella un cigarrillo con boquilla también dorada y en la que también sus iniciales se entrelazaban según el diseño de un cotizado dibujante italiano ; volvió a inspirar profundamente para extraer de sus cuerdas vocales esa voz grave y bien modulada que lo hacía irresistible para las mujeres ; extrajo un encendedor pequeño y rectangular que hacía juego con la cigarrera y lo aproximó al extremo del cigarrillo que acababa de colocar junto a la comisura derecha de sus labios pero sin llegar a encenderlo para crear el grado justo de tensión expectante-, dio a su mirada una intensidad particularmente atenta y dijo :

$7 \quad$ - Bien?

8 La cliente, una rubia probablemente teñida en un salón de primera categoría, que aparentaba unos veinticinco años pero cuya verdadera edad oscilaría entre los treinta y los cincuenta, permaneció silenciosa, mirándolo fijamente con los ojos muy abiertos, con ese feo rictus que la desmejoraba sensiblemente, como si estuviera muy angustiada, asustada, como conteniendo un grito.

9 -¿Bien? -repitió Carter, sin mejor resultado. Pulsó nerviosamente el botón del intercomunicador, ubicado en el ángulo inferior derecho del lustroso rectángulo de la tapa de su escritorio.

10 -jJefe! -se oyó gritar con entusiasmo a través del pequeño parlante del intercomunicador.¡Por fin ha vuelto!

11 -Grey Hound talking, Grey Hound talking -pronunció Bill con voz ronca, apenas susurrada. Esa era la clave para ser reconocido, por su secretaria-. ¿Me quieres decir quién es esta dama, cómo hizo para entrar aquí y por qué no habla? Over.

12 Virginia entró por la puerta que da al despacho, rodeó el escritorio y después el cuello de Billy con sus brazos ebúrneos. Estaba vestida. Billy la miró con furia, haciendo señas con los ojos hacia la dama que los estaba mirando fijamente, con ese feo rictus en el rostro que la hacía aparecer como a punto de dar un grito de horror.

13 -Explícame la presencia de esta dama -dijo secamente, liberándose del abrazo. La joven, que no comprendía los motivos de la frialdad de su patrón, habló con resentimiento.

14 -Hace tres días que está allí -repuso-. No hubo forma de impedirle que entrara a su despacho, ni de hacerla esperar en la antesala. Quiere hablar con usted, y sólo con usted, y manifestó que no se movería de alli hasta que no lo hubiera conseguido.

15 ¿Y ahora por qué no quiere hablar?

16 Virginia miró detenidamente a la mujer. Después hizo pasar respectivamente la mano derecha antes aquellos ojos fijos, y dijo al fin :

17 -Parece que está en estado de shock... No comprendo; hace apenas una hora estaba lo más bien, hasta comió un par de sándwiches que le trajo Tinker. Tinker ha ganado bastante con las generosas propinas de esta dama por sus pequeños mandados...

18 -No me importa en este momento Tinker, ni sus ganancias. Quiero saber qué le pasa a esta maldita mujer.

19 -Algo debe de haberla asustado. Algo de esta misma oficina... jJefe! -exclamó repentinamente Virginia, como un gritito agudo. Billy se puso en pie de un salto, llevando la mano a la sobaquera; en un instante tenía la pistola de cachas nacaradas en la diestra, y apuntó barriendo todo el campo visual del recinto en un rápido giro del torso sobre las caderas. 
Luego se distendió, al comprobar que no sucedía nada ; nada más que una idea que se le había ocurrido a Virginia.- jJefe! Usted no pasó por la antesala... Pensé que había usado la entrada secreta... pero no me diga que... -buscó en el piso, entre el sillón y la ventana, y resopló con furia-. ¡Otra vez! -rezongó-. ¡Otra vez entró por la ventana! ¿No vio que estaba cerrada? Mire, mire el piso lleno de fragmentos del vidrio... ¿Por qué, Dios mío, por qué no se acostumbra a usar la puerta? Justamente hoy, que vino la limpiadora. iFíjese cómo ha quedado la pobre alfombra, cómo ha quedado la pobre ventana, cómo ha quedado la pobre mujer! ¡Oh Dios! Billy encendió por fin su cigarrillo y meditó unos instantes.

21 ¿¿Tú dices que ella ya estaba sentada allí cuando yo entré? Hmmm. No me di cuenta. ¿Tú opinas entonces que ella se ha asustado por mi manera un poco brusca de aparecer?

-Desde luego. Y probablemente, imagino que habrá dado ese famoso alarido suyo mientras atravesaba el vidrio, ¿verdad?

23 -Es posible -respondió Billy, observando ahora con mayor atención a la cliente. Rodeó el escritorio y acercándose a ella comenzó a darle pequeños masajes en la espalda y el cuello. -Está completamente rígida -comentó-. Lo peor de todo es que cuando salga del shock, va a gritar. Y a mí los gritos de las mujeres... -ahora masajeaba suavemente el pecho, y pareció adquirir mayor interés aún en la cliente Aflojó unos botones del vestido e introdujo la mano entre el vestido y la piel-. Puedes retirarte -dijo.

24 Virginia hizo un movimiento que sugería que iba a protestar violentamente, pero una mirada muy fría de Billy Carter la cortó en seco. Entonces ella dio media vuelta y salió taconeando del despacho, cerrando con un portazo. Más tarde salía Billy por la misma puerta.

25 -Ahora está descansando apaciblemente -dijo, haciendo una señal con el prominente mentón hacia el despacho. Yo voy a casa a dormir un rato. Vengo de un viaje muy largo, de una aventura realmente agotadora. Tú vístela, para que no tome frío, y atiéndela cuando despierte. En todo caso dale un par de aspirinas. Seguramente despertará gritando, y no quisiera estar cerca cuando lo haga ; los gritos de las mujeres me... Un espantoso y desgarrador grito de mujer, que parecía el primero de una larga serie que vendría a continuación, y que provenía del despacho, cortó sus palabras.

27 -Cóbrale lo habitual. Vuelvo más tarde -gritó Billy desde la puerta y se lanzó apresuradamente escaleras abajo.

(No se pierda el próximo episodio : "Las fotos comprometedoras") 